\title{
SPECIAL EQUIPMENT APPLICABLE IN ADMINISTRATIVE ACTIVITIES OF LAW ENFORCEMENT AUTHORITIES AS A LEGAL CATEGORY
}

\section{Kharaberiush I. F.}

\section{INTRODUCTION}

The existence of offenses and their destructive influence on almost all processes occurring in the state, and encourages state law enforcement agencies to continuously improve methods and measures to counteract these negative phenomena.

Such reaction of law enforcement agencies is necessary to ensure public and personal security of society as a whole. Reckless disregard for even minor administrative violations by law enforcement leads to a decrease in confidence in the system of protection of citizens, legal nihilism, growing crime, and other related negative social phenomena.

The formation of Ukraine as democratic, social, rule of law largely depends on the stability of social relations, protection of rights, freedoms and interests of man and requires effective law enforcement. The contents of administrative law enforcement activities is the performance of duties on protection of public safety and order, combating crime and crime prevention, as well as creating conditions for the realization by individuals of their rights and legitimate interests ${ }^{1}$. Essential in the process of becoming a democratic state and efficient administration of law enforcement agencies is played by scientific and technical means that we collectively are defined as a special technique of law enforcement.

Interdisciplinary legal category of "a special technique of law enforcement" ${ }^{2}$ brings together all the technical tools that are used in law enforcement activities, and divided according to their professional spraymount on the forensic (investigative activities), operational (operational-search activity) and organizational (administrative activities).

If forensic and surgical technique have quite a developed system of studies and emerged as a separate category of law - the organizational machinery for such a system does not and requires separate consideration.

\footnotetext{
${ }^{1}$ Адміністративна діяльність Національної поліції : навчальний посібник для підготовки до іспиту / О.М. Калюк, С.Ф. Константінов, В.А. Куліков та ін. ; за ред. В.А. Кулікова. Київ : Освіта України, 2016. 230 с. С. 8.

Хараберюш І.Ф. Спеціальна техніка правоохоронних органів як міждисциплінарна категорія юридичної науки. Часопис Національного університету «Острозька академія». Серія «Право». 2019. № 1 (19). URL: http://lj.oa.edu.ua/articles/2019/n1/18hifkyn.pdf.
} 
Research the use of scientific and technical means of law enforcement have been studied by many scientists. But there is still no clear conceptual and structural certainty of special equipment used in administrative activities, the definition of its system, the interpretation of it as a legal category. We need to determine the location of special equipment used in administrative activities, to determine its system, to provide a General characterization of the organizational technique and describe its classification.

\section{The concept of organizational technology as a legal category}

One of the components of the law enforcement activities of the police is an administrative activity, which differs in scope and content tasks the relevant agencies and police departments. Administrative activities are carried out through legal and administrative means and are aimed at protecting public order, ensuring public safety ${ }^{3}$. One of the effective means of realization of administrative activity there is a special technique of law enforcement.

The necessity of using special equipment in law enforcement bodies of Ukraine and administrative activities in particular due to many factors:

- the use of special equipment greatly expands the physical capabilities of man, which in turn improves the performance of official and social activities of employees in all areas of the operation of law enforcement bodies;

- the use of special equipment in the process of improving the information support of law enforcement activities, the entire information infrastructure of law enforcement agencies of Ukraine leads to increased efficiency of management decisions, the optimal number of law enforcement units;

- in the process of law enforcement activities on the prevention of crime, collection of primary data, the use of special equipment makes it possible to avoid influences of subjective factors and significantly increases the level of objectivity of such data;

- the use of special technical systems allows to significantly increase the reliability of separate continuous functions of law enforcement agencies (security systems, alarm systems, video surveillance systems, and the like);

- effective counteraction to modern criminal gangs, neutralization and prevention of their activity is impossible without special equipment, which is a consequence of the high technical equipment of such groups ${ }^{4}$.

We previously argued that the concept of "special equipment" is generic, and is most useful to classify its activities, which also contributes to the system of the current legislation governing the use of special equipment for

\footnotetext{
${ }^{3}$ Адміністративна діяльність міліції : підручник / за заг. ред. О.М. Бандурки. Харків : Вид-во Нац. ун-ту внутр. справ, 2004.

${ }^{4}$ Бандурка О.М. Оперативно-розшукова діяльність : підручник. Харків : Вид-во Нац. ун.-ту внутр. справ, 2002. 336 с. С. 7.
} 
various services. Thus, a special technique can be classified for operativeinvestigative, investigative and administrative activities ${ }^{5}$.

However, recognizing such a division of special equipment in the direction of law enforcement agencies, scientists in the future does not explore systematically the conceptual-structural complex of special equipment General and office equipment in particular. Individual scientists define special equipment as the system hardware and relevant tactical techniques, which are applied by the bodies of internal Affairs in strict compliance with the law in the fight against crime, ensuring public order and perform other duties assigned to them. While the technical means they include seven major classes: communication; alarms and industrial television; operational-technical means (tools unofficial photography and video recording, means of covert recording, search devices; night surveillance; special chemicals); reconnaissance and technical information protection; forensic engineering; information systems; means of individual protection and active defense ${ }^{6}$. In this definition, special machinery tracked the main directions of the use of technology in activities of internal Affairs bodies, but there is no clear clasific these means used in administrative activities.

Some scientists consider special equipment within all law enforcement agencies ${ }^{7}$, but also do not lead to a logical conclusion the legal definition that we are considering.

In works of scientists sometimes found the definition of art that is used for administrative activities, is a set of technical means applied in a transparent manner, to ensure the protection of public order and public safety. Technical tools, devices, and methods for their use are developed or adapted depending on the direction of administrative activities of internal Affairs bodies and goals of their application. These include tools, office equipment, special vehicles, technical means of traffic control, etc. the Application of this technology is regulated by norms of administrative law ${ }^{8}$. In this work there is also uncertainty regarding organizational technology and its precise classification.

Question the usage of the special equipment in administrative law enforcement activities, we try to consider based on the content of administrative

5 Хараберюш І.Ф. Протидія злочинності засобами спеціальної техніки: концептуальний підхід. Монографія. Донецьк : Ноулідж, 2011. 362 с. С. 26.

${ }^{6}$ Мукоіда Р.В., Шелехов А.О. Спеціальна техніка в органах внутрішніх справ : навчальний посібник / за заг. ред. С.В. Кузніченка. Одеса : ОДУВС, 2013. С. 5.

${ }_{7}^{7}$ Специальная техника правоохранительных органов : учебное пособие / сост. : Е.Р. Пудаков, Р.Р. Яппаров. Уфа : Изд-во БИСТ (филиал) ОУП ВО «АТиСО», 2017. С. 7; Леонов С.Н., Попов В.Г. Специальная техника правоохранительных органов : курс лекций. Томск : Кузбасский институт ФСИН, 2010. С. 6; Быстряков Е.Н., Савельева М.В., Смушкин А.Б. Специальная техника : учебное пособие. 2-е изд., стер. Москва : ЮСТИЦИЯ, 2018. С. 10.

${ }^{8}$ Кемпф В.А. Основы применения специальной техники в профессиональной деятельности сотрудника полиции : учебное пособие. Барнаул : Барнаулский юридический институт МВД России, 2016. 70 с., с. 6. 
activity of the police is to fulfil the responsibilities to ensure public safety and order, fight against crime and crime prevention, as well as creating conditions for the realization by individuals of their rights and legitimate interests. The administrative activities of the police is divided into two types:

1) in-system. Snooty administrative activities aimed at ensuring the effective functioning of all departments and services, efficient work of employees, as well as the rational use of energy and resources. It includes: definition of the structure, States, work planning, control and verification execution of, the dissemination of good practices, placement and training of personnel, certification of personnel, record keeping. This activity applies to paparattorovanie divisions and has a subsidiary character in relation to the external.

2) external (law enforcement). External administrative activities outside of the police system and applies to napedowy her state and public organizations, and citizens. Following her directions:

- the protection of public order;

- ensuring public safety (rules of the permit system, road safety);

- protection of property;

- licensing activities;

- protection, maintenance, and escorting persons;

- the functioning of the special institutions of the police;

- preventive work ${ }^{9}$.

To determine the scope of the concept of "organizational technique", we apply the method of selecting criteria. When defining organization techniques as a basis we take the following indications:

- interpretation of the definition of "organization" (from the Greek. ópyavov - tool) as a target to achieve a certain goal. The term "technique" refers to, firstly, the totality of the instruments of labor, tools with which to create something, and secondly, directly to the machines, tools, devices, and thirdly, a body of knowledge, tools, methods, and techniques used in some cases ${ }^{10}$. "Specialty" organizational technology in this case is determined by its target priznachennya ${ }^{11}$ and allows the total Arsenal of scientific and technical means to allocate funds and methods to ensure the solution of problems of administrative law enforcement;

- requirements for the use of organizational and technical means. Due to the nature of the application to meet such requirements of scientific validity that must be provided by a system of state standards and certification of related

9 Адміністративна діяльність Національної поліції : навчальний посібник для підготовки до іспиту / О.М. Калюк, С.Ф. Константінов, В.А. Куліков та ін. ; за ред. В.А. Кулікова. Київ : Освіта України, 2016. 230 с. С. 10.

${ }^{10}$ Ожегов С.И. Словарь русского языка: 70000 слов / под ред. Н.Ю. Шведовой. Москва : Рус. яз., 1990. С. 795.

11 Хараберюш І.Ф. Спеціальна техніка правоохоронних органів як міждисциплінарна категорія юридичної науки. Часопис Наџъіонального університету «Острозька академія». Серія «Право». 2019. № 1(19). URL: http://lj.oa.edu.ua/articles/2019/n1/18hifkyn.pdf. 
equipment; the reliability, i.e. the ability of long-term work (including offline) in any climate and weather conditions; safety, i.e. avoidance of harm to the life and health of people and the environment, and the like;

- the subject of the application, which are the law enforcement agencies that implement the administrative function. In this vipadku as subjects, we consider the relevant authorities and police units that perform administrative activities, which differs in scope and content of the tasks. Administrative activities are carried out through legal and administrative means and are aimed at protecting public order, ensuring public security. The law of Ukraine "On the National police" from 02.07.2015 and regulations of the National police from 28.10.2015 identify the key measures that make the National police of Ukraine in the framework of the administrative activities;

- the conditions of application of the organizational machinery. Organizational-technical means can be divided in relation to areas of administrative activity, carried out in accordance with the rules of administrative law (through the services of public order protection, protection of objects, etc.);

- the direction of application of the organizational machinery for the implementation of the functions of protection of public order, ensuring public safety, protection of property, maintenance works and the like.

Based on the recognition of the definition of "special technique" as a generic, generic concept, we can say that organizational technology is a special technique used in administrative activities. Organizational technology can be defined as a set of organizational and technical means and methods of their legitimate use in order to fulfill the tasks of administrative activities by law enforcement agencies. Organizational and technical means, according to this definition, include - technical, software and software tools, special devices, substances, automated and intelligent systems. The methodology of application of organizational technology is a scientifically grounded tactical techniques, methods and information technologies.

\section{System-structural structure of organizational technique}

Further development of our study should be the definition of the systemstructural structure of the organizational equipment of law enforcement agencies as a scientific category according to selected criteria.

For this we turn to the classical theory of organization. A significant role in the development of organization theory played a German sociologist M. Weber, who described the ideal organizational structure that ensures the optimization of all structural Association (e.g. law enforcement authority). He believed that such basic elements of organizational structure as the division of labor by functional specialization, hierarchical system of power distribution, formalized system of procedures, rules and regulations to determine rights and obligations of employees and their behavior in specific situations, the recruitment and promotion of employees in accordance with 
their competence and domestic needs, the anonymity of the relationship, will provide the speed, precision, order, certainty, continuity and predictability of the structural activities of the Association. A system built in accordance with these principles, called hierarchical structure ${ }^{12}$. In accordance with the pp. 3.5.1 ISO 9000 "Systems of quality management. Basic provisions and vocabulary", the system is a set of interrelated or interacting elements. Standardization contributes to the combination of institutional elements, in our case a law enforcement Agency that performs administrative functions, sistematski relationships, thus creating preconditions for the emergence of synergetic effect ${ }^{13}$. The hierarchical structure of law enforcement units carrying out administrative activities (mainly the police) will serve as the basis of systematization of the organizational machinery.

By analogy with the special equipment, organizational technique as a branch of knowledge represents the totality of knowledge, which in a certain sequence according to their importance, relationships and relationships. Like every science, organizational technique has its own system, which has evolved over time and requires a clear definition with regard to the requirements ${ }^{14}$.

Using the deductive method, we can say that the system of organizational technology, as a section of special technics of law enforcement agencies, is composed of elements that include general provisions and branches of organizational technology. General provisions should define the basic concepts, system, principles of use, tasks of organizational technology, the general characteristics of organizational equipment, techniques and methods of their application, legal regulation in solving problems of administrative activities.

The branches of organizational technology of law enforcement agencies should consist of the main directions of its use in administrative activity. According to the directions of use, it can be considered in relation to the management of the activities of law enforcement agencies - management, security and public safety - security, property protection - security equipment.

Tools office equipment, we believe, can be classified according to the following criteria: the source of origin; application.

Regarding the sources of funds, the organizational techniques can be divided into three large groups: General use (adapted) for General use with minor alterations (modified) and specially designed (unique).

The purpose of the organizational-technical means can be considered, given their technical capabilities, which are used to implement

${ }_{12}^{12}$ Вебер М. Избранные произведения. Москва : Прогресс, 1990. 808 с.

13 Новаківський I.I. Система управління підприємства в інформаційному суспільстві : дис. ... докт. економ. наук : 08.00.04. Львів : Національний університет «Львівська політехніка», 2017. 494 с. С. 19-20.

14 Хараберюш I.Ф. Спеціальна техніка правоохоронних органів як міждисциплінарна категорія юридичної науки. Часопис Національного університету «Острозька академія». Серія «Право». 2019. № 1(19). URL: http://lj.oa.edu.ua/articles/2019/n1/18hifkyn.pdf. 
administrative forms of law enforcement. On purpose they are, we believe, are divided into: a means of recording information; means of organization of management (communication, speech amplification system of collection, accumulation and analysis of information); technical security equipment; search equipment; monitoring and control; protection and the like.

Given the fact that we are a General characteristic of the special techniques of law enforcement and its components has been discussed previously ${ }^{15}$ we elaborate on the areas of organizational equipment.

Administrative law as an integral part of the legal system of the state is characterized primarily in that it acts as a regulator of a special category of social relations, namely relations that develop within the field of public administration. The term "administrative" in Latin means "manage". Therefore, the phrase "administrative law" it is quite natural to interpret it as a "management right", and the term "administrative law enforcement" as "administrative law enforcement". The term "management" means activities to guide something. In the literature there are several definitions of the essence of management. Most often it is understood as an activity which directs and regulates social relations; the set of instruments and mechanisms which result in movement of the machine; units in the system of the institution; the kind of syntactic dependencies and the like ${ }^{16}$.

Control system pravoohranitel bodies as every control system has four elements: management subject - the one who leads; a control object - that is guided by the subject of management; a direct link is the influence of the subject on object of management; feedback is informing the object of control in appropriate form about the perception or rejection of the governing influence of the subject of management. In this system, the channels and organize the means of support of management activity - management techniques.

Control technology is designed to provide uninterrupted connection of subject and object control. In its composition, we believe, include: communications, enhance speech, surveillance, information and intelligent systems.

${ }^{15}$ Хараберюш І.Ф. Спеціальна техніка правоохоронних органів як міждисциплінарна категорія юридичної науки. Часопис Національного університету «Острозька академія». Серія «Право». 2019. № 1(19). URL: http://lj.oa.edu.ua/articles/2019/n1/ 18hifkyn.pdf.; Хараберюш І.Ф. Пртотидія злочинності засобами спеціальної техніки: концептуальний підхід : монографія. Донецьк : Ноулідж, 2011. 362 с.; Хараберюш І.Ф. Використання спеціальної техніки щодо протидії злочинності в Україні: теоретичні, правові та організаційні аспекти : монографія. Львів : Львівський державний університет внутрішніх справ, 2011. 284 с.; Хараберюш І.Ф. Спеціальна техніка правоохоронних органів: поняття та система. Вісник Маріупольського державного університету. Серія «Право». 2019. Вип. 17. С. 32-40.

${ }^{16}$ Колпаков В.К. Адміністративне право України : навчальний посібник. Київ : Юрінком Інтер, 2004. 544 с. C. 6. URL: http://www.info-library.com.ua/books-text7900.html. 
In the explanatory dictionary of the Ukrainian language States that "the public" is what takes place in the presence of people, the public; intended to visit or use the broad masses; public; public ${ }^{17}$. And a category of "public safety" reflects current trends of social and state development in a direction that corresponds to the priority of life, health and personal safety of man and citizen, its prosperity and well-being ${ }^{18}$.

So under public safety and can understand the preservation of the rule of law from threatening events and values of the citizens of the state and society as a whole, as well as the actual condition which makes it impossible for their normal functioning, implementation of guaranteed by law rights, freedoms and interests, preservation of property, health and life of people ${ }^{19}$. The effectiveness of protection and ensure public safety is largely dependent on the tools that guarantee the safety of the personnel of law enforcement bodies performing protection of a public order and traffic, namely, safety.

Safety, we can include: special tools, a means of recording and monitoring, search tools ${ }^{20}$, controls of road safety ${ }^{21}$.

An explanation requires an approach to the election and use of means of control of road safety and the dissemination of this approach to other tools of organizational engineering. So the measurement tools used to monitor the road safety (alcohol testers, gas analyzers, speed meters, flaw detectors, etc.), in accordance with the Law of Ukraine "On Metrology and metrological activity" dated 05.06.2014, N 1314-VI, subject to certification (art. 16) and periodic verification and verification after repair (art. 17).Therefore, the only and decisive requirement of the current legislation for measuring equipment that has already been introduced or is about to be put into operation is the need for their certification and periodic verification. We believe that this approach should be extended to other law enforcement special equipment in general and to organizational technology in particular.

The essence of the application of technical means for the protection of various objects is quite simple. It consists in equipping the protected object with devices capable of recording any unauthorized attempts to penetrate the

${ }^{17}$ Словник української мови : в 11 т. Київ : Наук. думка, 1977. Т. 8.927 с. С. 383.

18 Батраченко О.В. Поняття та ознаки публічної безпеки та порядку як об'єктів адміністративно-правової охорони. Науковий вісник Ужгородського начіонального університету. 2014. Вип. 29. Ч. 2. Т. 3. С. 84-86. С 85.

${ }^{19}$ Проневич О.С. Роль і місце поліції в системі органів публічної адміністрації Польщі. Форум права. 2010. № 4. С. 741-747. С. 743.

${ }^{20}$ Хараберюш І.Ф. Спеціальна техніка в правоохоронній діяльності : навчальний посібник. Маріуполь : МарДУ, 2017. 311 с. С. 164-206; Improvement of the legal culture as a basis for the formation of civil society of modern times : collective monograph / O. Borschevska, O. Boryslavska, I. Kharaberiush, O. Krushnitska, etc. Lviv-Toruń : LihaPres, 2020. 164 p. P. 42-57. URL: https://doi.org/10.36059/978-966-397-191-9/42-57.

${ }^{21}$ Спеціальна техніка : підручник / І.С. Керницький, Б.В. Щур, І.Ф. ІХараберюш, А.В. Мовчан, В.М. Слижук. Львів : Львівський державний університет внутрішніх справ, 2010. 356 с. С. 244-346. 
object or causing a fire at the object and automatically generate an alert (alarm) of the security personnel, which we define as security equipment.

Security equipment is a set of certified security equipment (intruder alarm) and methods that are lawfully used for the detection, recording, research, evaluation and use of information for the protection of objects. System security technology is determined by two criteria: by application; by functional purpose. In the application of technical means of security technology is divided into three groups: security; fire; fire. Functionally, they are classified into two groups: - detection equipment (sensors) that can be used to obtain information about the status of the monitored parameter; technical means of notification intended for reception, conversion, transmission, storage, processing and display of information coming from the sensors ${ }^{22}$.

Considering organizational technique as a set of organizational and technical means and methods of use of these funds, we can't ignore the prospect of its development. We see this process in the development and implementation of intelligent systems that improve the efficiency of administrative activities.

The concept of "intelligent systems" is derived from the category of "intelligence" (lat. Intellectus - mind; thinking abilities) and it is associated with the concept of "artificial intelligence". In the contemporary philosophical literature, it is considered as a set or system of cognitive abilities of the people, manifested in ease of learning, ability to quickly and easily acquire new knowledge and skills in overcoming unexpected obstacles in the ability to find solutions to non-standard situations, ability to adapt to complex, changing, unfamiliar environment, deep understanding of what is happening, in the works ${ }^{23}$.

Modern understanding of intelligent systems emerged in the process of development of theoretical bases of Cybernetics modern control theory, theory of algorithms, development of new information technologies and the generalization of the accumulated scientific knowledge, methods and tools in the field of artificial intelligence. It should be noted that the modern theory of artificial intelligence and established on the basis of intelligent systems and technologies was produced by the labor of many researchers over many years.

In the literature of the theory of artificial intelligence and intelligent systems associated with the work of Alan Turing, in which he showed the possibility of creating a universal computer, able to solve mental tasks, and proposed a criterion test of his intelligence. Criterion has been considered the computer with the help of correspondence to convince the jury that he is a man. This criterion was later named "Turing test". This is an example of the definition of intelligence as the ability to simulate human actions. This idea of intelligence is a characteristic of the entire early history of artificial

\footnotetext{
${ }^{22}$ Хараберюш І.Ф. Спеціальна техніка в правоохоронній діяльності : навчальний посібник. Маріуполь : МарДУ, 2017. 311 с. С. 230-231.

${ }^{23}$ Всемирная энциклопедия. Философия. Москва : АСТ, 2001, 1312 с. С. 518.
} 
intelligence and became the starting point for the development of discussions about the possibility of artificial intelligence and intelligent systems ${ }^{24}$.

Further research in the field of artificial intelligence greatly influenced the work of D.A. Robinson and other scientists ${ }^{25}$. The value of these works lay in the fact that the main attention in artificial intelligence research has shifted from developing techniques to play in the computer of the human mind to develop a machine-oriented methods of solving practical problems (functional approach). Functional approach to artificial intelligence research remained mostly up to date.

The concept of "artificial intelligence" is usually interpreted as a property of information systems to take on certain functions of human intelligence, namely the following intellectual functions:

- communicative abilities - a way of interaction of the system with the end user and with another intelligent system;

- analytical capabilities - solving complex poorly formalized tasks that require the construction of a solution algorithm, depending on the specific situation, which is characterized by the uncertainty and dynamic of the initial data and knowledge;

- the ability to self-study - the ability of the system to automatically acquire knowledge from experience and apply them to solve problems;

- adaptability - the ability of the system to develop in accordance with objective changes in the field of knowledge;

- the ability to self-esteem - possession of the means to evaluate the results of their own work;

- creativity - covers the compilation of poems, computer music, games, the invention of new objects ${ }^{26}$.

Each of these features is conditionally responsible for its class of intelligent systems. Different systems may have one or more intellectual traits with varying degrees of manifestation.

On the basis of generalization of research results in the field of intelligence and intelligent systems in law enforcement we have to understand that the process of providing law enforcement in General and administration in particular systemic properties of intelligence. This process should serve as a factor of intensive development and a tool to improve efficiency in administrative activities through the development and implementation of new technologies in the following areas:

- information-analytical support of law enforcement. An example of such an intelligent system can be Integrated information retrieval system of

${ }^{24}$ Хараберюш І.Ф. Інтелектуальні системи в правоохоронній діяльності. Вісник Маріупольського державного університету. Серія «Право». Маріуполь : МДУ, 2018. Вип. 16. С. 39-45. С. 40.

${ }^{25}$ Гороховський O.I. Інтелектуальні системи : монографія. Вінниця : ВНТУ, 2010. 193 с. С. 6-7.

${ }^{26}$ Хараберюш І.Ф. Інтелектуальні системи в правоохоронній діяльності. Вісник Маріупольського державного університету. Серія «Право». Маріуполь : МДУ, 2018. Вип. 16. С. 39-45. 
the internal Affairs bodies of Ukraine ${ }^{27}$, which is designed to support the operational activities of bodies and divisions of internal Affairs and other cooperating law enforcement agencies, a substantial strengthening of their capacities for combating and preventing crime, which requires development and improvement to the Single computer information system for law enforcement agencies on combating crime;

- informational support of law enforcement activities. This direction of development of intelligent systems is associated with the emergence of geographic information systems, which provide information about spatial arrangement of objects using maps or plans.

- the development of intelligent video surveillance systems. The functionality of the whole object of the software of intelligent video surveillance systems is divided into two large groups: the recognition and classification of objects of surveillance; tracing the object of surveillance. This area requires improvement and development in the law enforcement system;

- protection of objects. This type of systems include systems centralto protection of objects of "Orlan", "KRONOS", "AI-Grifon" and so on, which is essentially a set of technical means and software for centralized monitoring devices, burglar and fire alarms using the GSM network900/1800 and wire lines of the telephone exchange;

- creation of departmental specialized intelligent information systems. Examples can be: for the border service Integrated information system "Arkan" and "Garth"; for the Ministry of revenues and duties is a multifunctional integrated information system "Electronic customs", etc.;

- implementation and development of intelligent educational information systems: modeling knowledge, communication, interpretation, selfimprovement; interaction.

Such systematization of intellectual systems used in administrative activity is, in a sense, rather conditional. We have just outlined the most promising areas for law enforcement agencies to use intellectual systems to systematically organize the process of countering administrative offenses. In the long term, all systems used to combat administrative offenses should be integrated and comprehensively used to rank information access levels.

Summing up, we can say that organizational technique is a set of organizational and technical means and methods of their lawful use in order to perform law enforcement tasks of administrative activities. To organizational-technical means, technical, software, hardware and software, special devices, substances, automated and intelligent systems. Methods of applied organizational technology is scientifically based tactics, techniques, and information technology.

The system office equipment are items, which includes General provisions and office equipment. General provisions should define the basic concepts, system, principles of use, tasks, organizational techniques, General

\footnotetext{
${ }^{27}$ Хараберюш І.Ф. Спеціальна техніка в правоохоронній діяльності : навчальний посібник. Маріуполь : МарДУ, 2017. 311 с.
} 
characteristics of means of organizational equipment, techniques and methods of their application, legal regulation in solving problems of administrative activities.

The branches of organizational technology of law enforcement agencies should consist of the main directions of its use in administrative activity. According to the directions of its use, it can be considered in relation to the management of the activity of law enforcement agencies - control technology, safety and public safety - security technology, property protection - security equipment.

The only definitive requirement of the current legislation to means of organizational equipment, which has already entered or planned to enter into operation, is the need to implement certification and periodic calibration.

The process of increasing the efficiency of administrative activities should be developed by intensive development, the development and implementation of new information technologies and intelligent systems.

\section{CONCLUSIONS}

Problems of the use of technical means in administrative activity is a fundamental multifaceted problem, which can be found only through the development of a set of interdependent measures based on a common understanding of the essence of organizational technology, the role and place of this technology in the activities of law enforcement units.

However, the use of organizational technology is defined not only by expediency and efficiency of administrative punishment. This should be evaluated also from the point of view of legality. This means that in all cases it should be strictly based on the norms of law and subordinate regulations, and any operational, organizational and other considerations justified to be. The legality is determined by one of the main principles of organization and activity of law enforcement bodies on the use of organizational techniques.

The principle of legality in law enforcement activities is the main idea of the position, expressing the content of law in the use of organizational techniques, which include:

1. The legitimacy of the use of organizational equipment. The main condition for the legality of the use of funds office equipment to perform the tasks of administrative activities is the use of every kind of means and methods in strict accordance with the Laws of Ukraine and requirements of the regulations and departmental normative acts by unauthorized persons.

2. Strict observance of the rights and interests of citizens guaranteed by law. The use of funds office equipment should not humiliate the honor and dignity of citizens, to cause physical harm, harm to their health.

3. The scientific validity of the potential of the organizational machinery. The contents of this requirement includes the need to use scientific-technical means, which are based on well understood phenomena and processes have been certified and tested, providing the objective, reliable data. The accuracy 
of obtaining the results includes obtaining each time the same results in similar conditions.

4. The actual grounds for the application of organizational engineering. The use of organisational techniques should be carried out only if there are sufficient grounds for the application, for example, of special means of active defense.

5. Targeted applications organzation technology. The use of organisational techniques should be aimed at protecting the interests of the state, rights and freedoms of citizens from encroachments on the part of offenders.

6. Documentation of the use of organizational techniques and of the obtained results.

In general, compliance with the law when using organizational technology is:

- in the obligatory adoption of measures stipulated by the norms of the laws that regulate the sphere of activity of administrative bodies;

- in implementation of these measures in strict accordance with the provisions of laws and by-laws of the departmental normative acts;

- inadmissibility of actions, unforeseen by the law, and even more so, which contradict it.

\section{SUMMARY}

The article deals the role and place of technology used in the administrative activities of law enforcement agencies as a separate category of legal science. The factors that determine the need to use special equipment in the administrative activities of law enforcement agencies are identified. It is based on the doctrine of special equipment of law enforcement agencies, which we considered in previous studies. According to the theoretical conclusions about the branches of special equipment of law enforcement agencies, the equipment used in administrative activities is defined by us as organizational. The method of criterion selection is used to determine the scope of the concept of "organizational technique". The semantics of the phrase stand out from the criteria; subject, conditions and direction of application; system; classification; practical meaning. It is proved that the system of organizational equipment, as a section of special equipment of law enforcement agencies, consists of general provisions and areas of organizational equipment. Branches of organizational equipment of law enforcement agencies consist of the main areas of its use in administrative activities. By areas of use, it is considered in relation to the management of law enforcement agencies - management techniques, protection and public safety - security, property protection - security equipment. Means of organizational equipment are classified by source of origin and purpose. The only and defining requirement of the current legislation for organizational equipment that has already been introduced or is planned to be put into operation is the need for their certification and 
periodic verification. Perspective directions of development of organizational equipment are defined - development and introduction of intelligent systems.

\section{REFERENCES}

1. Адміністративна діяльність Національної поліції: навчальний посібник для підготовки до іспиту / О.М. Калюк, С.Ф. Константінов, В.А. Куліков та ін. ; за ред. В.А. Кулікова. Київ : Освіта України, 2016. $230 \mathrm{c}$.

2. Хараберюш І.Ф. Спеціальна техніка правоохоронних органів як міждисциплінарна категорія юридичної науки. Часопис Національного університету «Острозька академія». Серія «Право». 2019. № 1 (19). URL: http://lj.oa.edu.ua/articles/2019/n1/18hifkyn.pdf.

3. Адміністративна діяльність міліції : підручник / за заг. ред. О.М. Бандурки. Харків : Вид-во Нац. ун-ту внутр. справ, 2004.

4. Бандурка О.М. Оперативно-розшукова діяльність : підручник. Харків : Вид-во Нац. ун.-ту внутр. справ, 2002. 336 с.

5. Хараберюш І.Ф. Пртотидія злочинності засобами спеціальної техніки: концептуальний підхід : монографія. Донецьк : Ноулідж, 2011. $362 \mathrm{c}$.

6. Мукоіда Р.В., Шелехов А.О. Спеціальна техніка в органах внутрішніх справ : навчальний посібник / за заг. ред. С.В. Кузніченка. Одеса : ОДУВС, 2013.

7. Специальная техника правоохранительных органов : учебное пособие / сост. : Е.Р. Пудаков, Р.Р. Яппаров. Уфа : Изд-во БИСТ (филиал) ОУП ВО «АТиСО», 2017.

8. Леонов С.Н. Попов В.Г. Специальная техника правоохранительных органов : курс лекций. Томск : Кузбасский институт ФСИН, 2010.

9. Быстряков Е.Н., Савельева М.В., Смушкин А.Б. Специальная техника : учебное пособие. 2-е изд., стер. Москва : ЮСТИЦИЯ, 2018.

10. Кемпф В.А. Основы применения специальной техники в профессиональной деятельности сотрудника полиции : учебное пособие. Барнаул : Барнаулский юридический институт МВД России, 2016. 70 с.

11. Ожегов С.И. Словарь русского языка: 70000 слов / под ред. Н.Ю. Шведовой. Москва : Рус. яз., 1990.

12. Вебер М. Избранные произведения. Москва : Прогресс, 1990. $808 \mathrm{c}$.

13. Новаківський I.I. Система управління підприємства в інформаційному суспільстві : дис. ... докт. економ. наук : 08.00.04. Львів : Національний університет «Львівська політехніка», 2017. 494 с.

14. Хараберюш І.Ф. Використання спеціальної техніки щодо протидії злочинності в Україні: теоретичні, правові та організаційні аспекти : монографія. Львів : Львівський державний університет внутрішніх справ, 2011.284 с. 
15. Хараберюш І.Ф. Спеціальна техніка правоохоронних органів: поняття та система. Вісник Маріупольського державного університету. Серія «Право». 2019. Вип. 17. С. 32-40.

16. Колпаков В.К. Адміністративне право України : навчальний посібник. Київ : Юрінком Інтер, 2004. 544 с. URL: http://www.info-library.com.ua/books-text-7900.html.

17. Словник української мови : в 11 т. Київ : Наук. думка, 1977. T. $8.927 \mathrm{c}$.

18. Батраченко О.В. Поняття та ознаки публічної безпеки та порядку як об'єктів адміністративно-правової охорони. Науковий вісник Ужггородського національного університету. 2014. Вип. 29. Ч. 2. T. 3. C. 84-86.

19. Проневич О.С. Роль і місце поліції в системі органів публічної адміністрації Польщі. Форум права. 2010. № 4. С. 741-747.

20. Хараберюш I.Ф. Спеціальна техніка в правоохоронній діяльності : навчальний посібник. Маріуполь : МарДУ, 2017. 311 с.

21. Improvement of the legal culture as a basis for the formation of civil society of modern times : collective monograph / O. Borschevska, O. Boryslavska, I. Kharaberiush, O. Krushnitska, etc. Lviv-Toruń : Liha-Pres, 2020. 164 p. P. 42-57. URL: https://doi.org/10.36059/ 978-966-397-191-9/42-57.

22. Спеціальна техніка : підручник / І.С. Керницький, Б.В. Щур, I.Ф. Хараберюш та ін. Львів : Львівський державний університет внутрішніх справ, 2010. 356 с.

23. Всемирная энциклопедия. Философия. Москва : АCT, 2001,1312 c.

24. Хараберюш І.Ф. Інтелектуальні системи в правоохоронній діяльності. Вісник Маріупольського державного університету. Серія «Право». Маріуполь : МДУ, 2018. Вип. 16. С. 39-45.

25. Гороховський O.I. Інтелектуальні системи : монографія. Вінниця : ВНТУ, 2010. 193 с.

Information about the author: Kharaberiush I. F., ORCID ID: 0000-0002-4968-5421 Doctor of Law, Professor, Professor at the Department of Law and Public Administration Mariupol State University 129a, Budivelnykiv avenue, Mariupol, 87555, Ukraine 